\title{
TAX ENFORCEMENT PROCEDURE UNDER SECTION 104 OF PERSONAL INCOME TAX ACT: MATTERS ARISINGS
}

\author{
Kachi Bielu John* \\ Faculty of Law, Nnamdi Azikiwe University, Nigeria, Email: kachibielu@gmail.com
}

(Received: August 2020; Accepted: October 2020; Published: November 2020)

\begin{abstract}
The refusal of a taxpayer to respond or pay the tax due has always provoked the tax authority to approach the court with an ex-parte application in chambers. The result of this ex parte application arms the tax authority with a restraining order. With a detached team of policemen, the tax authority will storm the premises of the taxpayer, vandalize, forcefully drive out the tax payer and seal up the premises. All these arrangements and decisions are done behind the taxpayer. This paper examined the constitutionality of the entire procedure for the recovery of tax due to the tax payer. The paper utilized doctrinal methodology in analyzing the extant laws and case laws as they relate to the subject matter. The paper submits that decisions under section 104 PITA are too weighty to be taken in the absence of the taxpayer. The paper, therefore, recommends some sort of judicial activism by judicial officers in exercising their discretion and accommodate the interest of the taxpayer.
\end{abstract}

Keywords: Enforcement, Tax, Distrain, Demand, Assessment, Ex-Parte.

\section{Introduction}

Taxation spans over a wide gamut of human activity and is essentially aimed at providing the requisite revenue for the socio-economic development of a nation. Taxation [1] is the imposition or assessment of tax. It is the means by which the state obtains the revenue required for its activities. It is therefore the process of levying and collecting tax from taxable persons. It is the imposition, assessment and enforcement of payment of tax by the appropriate authority. Tax is a pecuniary burden laid upon individuals or persons or property to support the government which is exacted by legislative authority [2]. In Mathew v Chicory Marketing Board [3], a tax is defined as compulsory exaction of money by public authority for public purposes.

${ }^{*}$ Corresponding author: Kachi Bielu John.E-mail: kachibielu@gmail.com

Copyright (C) 2020 The Author(s). Published by VGWU Press

This is an Open Access article distributed under the terms of the Creative Commons BY 4.0 license (Creative Commons - Attribution 4.0 International - CC BY 4.0) which permits unrestricted use, distribution, and reproduction in any medium, provided the original author and source are credited.

156 Sciendo Journal of Legal Studies Volume 26 Issue 40/2020 
John, K.B., (2020)

Tax enforcement procedure under section 104 of personal income tax act: matters arisings

Citizens have a duty to obey, oblige and comply with the laws of the land and it is fundamental and concomitant with the duty of a citizen to pay taxes. A citizen is expected to declare his income honestly to the authorities promptly [4]. Even the scripture place much importance and emphasizes the payment of tax to the authorities [5].

Following the above, when a taxpayer fails or refused to respond or pay tax after he has been properly served with the assessment notice and demand notice, the tax authority will be left to enforce or the recovery of the tax due but unpaid. It is this move that sometimes provokes the tax authorities to take up the procedure for distraining the taxpayer of his chattels, properties, and others. This procedure has always been devastating to the taxpayer that he can only know about the litigation against him after unnecessary and avoidable embarrassments from the tax authority.

\section{Liability to Pay Tax}

Liability to pay tax is the obligation upon the individual and persons under the law [6] to pay taxes to the State. The legal basis for the liability to pay tax is that payment of tax or who is entitled to pay taxes is an issue of law not of agreement, contract, or compromise [7].

The power to impose a tax is inherent in the sovereignty and unlimited in the absence of constitutional restrictions but subject in the exercise to the discretion of the authorities in whom it is reposed [8]. The appropriate arm of the sovereign was reposed with the power of imposing taxes in the legislature. Unless the legislature makes a law on the payment of a particular tax, such tax should not be due for payment by the taxpayer or even be demanded by the Government. The following taxes are constitutionally classified to be paid;

i. Federal Taxes - Part 1 of the Exclusive Legislative List [9]. They are contained in items 16, 25, 58, and 59 of the Exclusive Legislative List. It includes Customs and Exercise duties, Stamp duties, taxes on corporate profits, and gains.

ii. State Taxes - They are contained in the concurrent legislative list particularly in items D paragraph 7 of part II of the first schedule [10]. This includes Income Tax, Stamp Duties on documents and transactions.

iii. Local Government Taxes -Tenement rates and other taxes enumerated under the fourth schedule to the constitution [11].

\section{Liability under Different Tax Laws}

A taxpayer must be in receipt of income or profit chargeable [12], that is not exempt [13], in order to be liable to pay tax. 


\subsection{Personal Income Tax Act (PITA)}

Subject to the provisions of this Act [14], the tax shall be payable for each year of assessment on the aggregate amounts each of which is the income of every taxable person, for the year, from a source inside or outside Nigeria including, without restricting the generality of the foregoing;

i. Gain or profit from any trade, business, profession or vocation, for whatever period of such trade, business, profession or vocation have been carried on or exercised [15].

ii. any salary, wage, fee, allowance or other gain or profit from employment including compensations, bonuses, premiums, benefits or other perquisites allowed, given or granted by any person to any temporary or permanent employment other than so much of any sums or expenses incurred by him in the performance of his duties and from which it is not intended that the employee should make any profit or gain [16].

iii. gain or profit including any premiums arising from a right granted to any other person for the use or occupation of any property [17].

iv. dividend, interest or discount [18]

v. any pension, charge or annuity [19]

vi. any profit, gain or other payment not falling within paragraphs (a) to (e) inclusive of this section [20].

\section{Institutions for Tax Administration:}

Tax authorities are those bodies that are reposed with the power of administration and collection of various taxes. There are also instances when the Federal Government or National Assembly due to preponderance of taxes, delegate the administration and collection of Federal taxes to states and agencies.

\subsection{The Federal Authority}

The Federal Tax Authority is reposed in the Federal Inland Revenue Service (FIRS) [21]. The object of the service is to control and administer the different taxes and laws specified in the first schedule to the Act or other laws made or to be made from time to time by the National Assembly or other regulations by the Government [22].

The service by the Act [23] is charged with the administration of Federal Tax statutes such as Personal Income Tax Act, Capital Gains Tax Act, Value Added Tax Act, and Stamp Duties Act. The Act [24] listed the functions of the service to include assessing persons including companies, enterprises chargeable with tax and assess and collect and enforce payment of taxes as may be due to the Government or any of its agencies. 


\subsection{State Tax Authority}

The State Board of Internal Revenue (referred to as the Board) with an operational arm as State Internal Revenue Service (SIRS) and known as State Service [25] collects taxes on behalf of the State Government. The major function of the SBIR is ensuring the effective and optimum collection of all taxes and penalties due to the government under the relevant laws [26].

\subsection{Local Government Revenue Committee}

There shall be established for each Local Government Area of a State a committee to be known as the Local Government Revenue Committee (referred to as the Revenue Committee) [27]. The committee is responsible for the assessment and collection of all taxes, fines, and rates under its jurisdiction and shall account for all amounts so collected in the manner to be prescribed by the chairman of the Local Government [28].

\section{Taxable Persons}

Tax is imposed on the income of individuals, communities and families and others arising or due to a trustee or estate. The total amount determined in accordance with the table in the sixth schedule of the Personal Income Tax Act shall be payable for each year of assessment on two categories of persons; viz:

(i) every individual other than persons covered under paragraph (b) of this subsection or corporation sole or body of individuals deemed to be resident for that year in the relevant State [29].

(ii) the following other persons [30];

a. persons employed in the Nigerian Army, the Nigerian Navy, the Nigeria Air force, the Nigeria Police Force other than in a civilian capacity.

b. officers of the Nigerian Foreign Service

c. every resident of the Federal Capital Territory Abuja.

d. a person resident outside Nigeria who derives income or profit from Nigeria.

Taxable person is any individual or body of individuals (including a family, any corporation sole, trustee or executor) having any income that is chargeable under the provisions of the Act [31].

\section{Tax Assessment}

The PITA is a statute containing 109 sections, all providing for different but connected guide or aspects of tax enforcement. Assessment of tax due from 
John, K.B., (2020)

Tax enforcement procedure under section 104 of personal income tax act: matters arisings

incomes chargeable is the process that culminates into the special procedure under section 104 PITA.

\subsection{Self Assessment}

A taxable person is required by the Act to file a return of income and shall in the return calculate the amount of tax payable in the form as may be prescribed by the minister by order in the gazettee. This statutory provision for self assessment [32] is reinforced by the provisions of section 41 PITA, thus;

For each year of assessment, a taxable person shall without notice or demand, therefore, file a return of income in the prescribed form and containing the prescribed information with the tax authority of the state in which the taxable person is deemed to be resident together with time and correct statement in writing [33].

Self-assessment therein provided a taxpayer opportunity to self-assess correctly about his income but this can only be defeated by his failure to file returns correctly or total failure or neglect to deliver a return. The assessment shall contain the amount from every source from the year preceding the year of assessment computed in accordance with the provisions of the Act and rules or regulations made [34]. The particulars by the return shall state such income, allowance, relief, deduction or otherwise as may be material for that purpose [35].

The onus of proving entitlement to the reliefs, allowances and deduction rest with the tax payer who will benefit from it [36]. On the other hand, a relevant tax authority may give notice in writing, when it thinks necessary requiring him to deliver within a reasonable time [37]. Again, for the purpose of obtaining full information, the relevant tax authority may exercise the power to call for returns, books, documents, and information [38].

Upon the receipt of such return prescribed, the relevant tax authority shall proceed to accept the returns or assess the taxable person based on the returns delivered [39]. On the other hand, where a taxable person fails to deliver the return or fails to deliver within the time prescribed, the relevant tax authority shall use its discretionary judgment [40].

\subsection{Assessment by Tax Authority}

Where a taxable person has delivered a return, the relevant tax authority may accept the return and make an assessment accordingly [41] or refuse to accept the returns and to the best of its judgment, determines the amount of the assessable, total, or chargeable income of that person and makes an assessment accordingly [42]. Any assessment by the relevant tax authority shall be based on the information supplied by the taxable person. The tax authority is empowered by law to issue a Notice calling for returns, books, documentation and information that 
will assist it in obtaining full information in respect of the income or gain of a person [43].

The notice shall contain:

i. Complete and deliver to the relevant tax authority any return specified in the notice.

ii. attend personally before an officer of the relevant tax authority for examination with respect to any matter relating to such incomes, gains;

iii. to produce any book, document, account, and return.

iv. give orally or in writing any other information required.

In FBIR $v$ Rezcallah \& Sons [44], the court held that the request by the tax authority for return to be rendered is a condition precedent for assessment.

Furthermore, where the tax authority did not accept the information contained in the returns, it posses the power to enter the premises and search [45]. An officer of the tax authority is empowered to enter, if necessary by force, the premises, registered office or place of management or the residence of the individual to conduct a search. In 1-D Sam v LSIRS [46] the claimant, an incorporated company was written by the defendant to verify their tax position and informed it of the necessity for a tax audit. However, for 7 months after the letter was issued, the claimant refused to allow the defendant access to its books and accounts despite several requests. Consequent to this, the defendant issued a demand notice to the claimant on its best of judgment. This is a wrong step following the extent of the law.

In GTB PLC v EKBIR [47], the court of Appeal reprimanded the tax authority and held that the next proper step from the combined reading of sections 55 and 104(1) to be taken by the tax authority ought to have been, an application to compel the surrender of the relevant facts, records and documents as it could not assess without the relevant facts and documents. This position is because, it is only when an assessment has been made, which is conclusive and final, demand notice thereof, communicated to the taxable person, with time limit within which payment should be made and there is default or non-compliance that there can be an invocation of the provisions of section 104(2) -(7), particularly subsection (4) which provide for the use of an ex-patre application and the order to distrain or warrant of distress issued by the court.

\subsection{Best of Judgment Assessment (BOJ)}

Where a taxable person intends to avoid or evade payment of taxes by either not filing his returns or submitting the returns which obviously does not represent the income of the taxpayer for the year of assessment, then the Board will invoke the powers conferred on it under the Act [48] and assess the taxpayer on its best of 
John, K.B., (2020)

Tax enforcement procedure under section 104 of personal income tax act: matters arisings

judgment. In FBIR $v$ FM Solanke [49], the court held that when the return of income is not accepted by the commissioner, he is entitled, indeed has a duty to make an estimated assessment. It is not necessary for the commissioner to give his reasons for arriving at his estimates.

In FIRS v GT [50], the court held that Best of judgment does not mean that no account, books or record are examined. Best of judgment need not be the worst of judgment. In ITC v Badridas [51], the court held that the officer has to make an assessment to the best of his judgment against a person who is in default as regards supplying information. He must not act dishonestly or vindictively or capricious, because he must exercise judgment in the matter. He must make what he honestly believes to be a fair estimate of the proper figure of assessment and for the purpose, he must be able to take into consideration local knowledge and repute in regard to assessee circumstances and his own knowledge of previous returns by and his assessment of the assessee and all other matters which he thinks will assist him in arriving at a fair and proper estimate. In some instances, there must necessarily be guess work albeit, honest guesswork, in making an assessment of the amount upon which in his judgment income tax ought to be levied and yet such an assessment is not ipso facto invalid.

In all, best judgment shall not be vindictive, arbitrary, or capricious. Where is it construed as a punitive measure, its impositions will be seen to be arbitrary, excessive, or capricious [52]. It must be based on a fair estimate of the taxpayer's profit [53]. Best of judgment assessment must not be premature. The tax authority shall not proceed to assess based on its best of judgment unless at the expiration of the time specified for the delivery of returns [54].

\section{Service of Notice}

The tax authority has a duty to serve upon the taxable person a notice stating the amount of any assessable, total or chargeable income, the tax charged, the place at which payment should be made and may state the rights of the taxable person. This is to be served on or sent by registered post or courier service or electronic mail [55]. In Fashogbon v Layode [56], the Court of Appeal interpreting section 57 of PITA on the steps that must be taken before the tax payable is evolved, held that to argue that serving notice of assessment on the taxpayer is not part of the procedure under the Decree is unthinkable. It is like staging a Romeo without a Juliet.

On the realm of the law, to say that the taxpayer whom, by the operation of the Personal Income Tax law is legally indebted to the tax authority for the assessed income tax is not entitled to be informed of the assessment of the income tax payable would be an imposition, an arbitrary act, that affects his civil rights and therefore, impinges upon his right of a fair hearing under section 36 of the constitution of the Federal Republic of Nigeria 1999. The conclusion is that the 
service of assessment of tax payable on a taxable income to the taxpayer is an essential requirement of the personal Income Tax. It is a sine qua non for establishing liability for non-payment of income tax. Lack of the two essential notices would render the assessment void. The notice requiring the taxpayer to submit his returns will show the amount of tax to which the taxpayer is assessed and informing him of his right to objection [57].

\section{Objections}

Upon service of notice of assessment and the taxpayer disputes the same, he may apply to the tax authority by notice of objection in writing, to review and revise the assessment [58]. The application shall state the grounds of objection and shall be made within 30 days of the service of the notice of assessment. In FBIR $v$ OWENA motels [59], upon service of demand notice by the plaintiff, the defendant did not raise objection in writing to the relevant tax authority. The court rejected the argument of the defendant that the plaintiff's BOJ was made arbitrary. The court held that the assessment has become final and conclusive after 30 days. Worthy of note, however, is that the present state of the law is that section 66 of PITA 2004 which made the provision for final and conclusive has been repealed.

In Ericsson $v$ BSBIR [60], the court held that it is an error of law for the Respondent to argue that its BOJ assessment has become final and conclusive, if it received no objection after 30 days of the service of a tax assessment. This is owing to the fact and express repeal of the erstwhile applicable section 66 PITA,2004, which has been repealed by the PITA, 2011 amendment.

\section{Appeal}

A person aggrieved by an assessment or demand notice made upon him by the service may appeal to the Tax Appeal Tribunal (TAT) within 30 days from the date of service of notice [61]. A notice of appeal is given to the appropriate tax authority set out in the Rules [62]. The secretary of the Appeal Tribunal shall cause the notice to be delivered to the relevant tax authority and list of the appeal for hearing appropriately. On the other hand, the relevant tax authority may after delivery of notice upon it by a taxpayer raise the assessment in agreement with the taxpayer and the notice of the same sent to the secretary of the tribunal.

\section{Power to Distrain}

This is a post-assessment power of the tax authority where other pre-distraining steps have been taken. The tax authority has taken the right steps in getting the taxpayer to pay his tax will resort to the procedure for enforcement stipulated under power to distrain [63]. Other procedural steps are alternative to the power to 
John, K.B., (2020)

Tax enforcement procedure under section 104 of personal income tax act: matters arisings

distrain, however, but the power to distrain is the most commonly used by the tax authorities.

Power to distrain is a creation of a right of access to court for the tax authority. The provisions of the Act [64] state;

Without prejudice to any other power conferred on the relevant tax authority for enforcement of payment of tax due from a taxable person, that has been properly served with an assessment which has become final and conclusive and a demand notice has been served on the person in accordance with the provisions of this part of this Act or been served upon the person, then if payment of tax is not made within the time limited by the demand notice, the relevant tax authority may in the prescribed form, to enforce payment of the tax due;

a. distrain the taxpayer by his goods or other chattels, bond or other securities or [65];

b. distrain upon any land, premises or places in respect of which the taxpayer is the owner and subject to the provisions of this section, recover the amount of tax due by the sale of anything distrained [66].

ii. The authority to distrain under this section shall be in the information prescribed by the relevant authority [67]

iii. For the purpose of levying any distress under this section, an officer duly authorized by the relevant authority shall apply to a judge of a High court sitting in chambers, under oath for the issuance of a warrant under this section [68].

iv. The judge may, on an application made ex-patre authorize such officer referred to in subsection (3) of this section in writing to execute any warrant of distress and if necessary, break open any building or place in the day time for the purpose of levying such distress and he may call for his assistance any police officer and it shall be the duty of any police offer when so required to aid and assist in the execution of any warrant of distress and in levying the distress [69].

v. The distress taken pursuant to this section may, at the cost of the owner, be kept for 14 days, at the end of which time, if the amount due in respect of tax and the cost and charges incidental to the distress are not paid the same may be sold [70].

vi. There shall be paid out of the proceeds of ksale, in the first instance, the cots or charges incidental to the sale and keeping of the distress and the residue, if any, after the recovery of the tax liability, shall be payable to the owner of the things distrained or to the appropriate court where the owner cannot be traced, within 30 days of such sale [71].

vii. In exercise of the powers of distress conferred by this section, the person to whom the authority is granted under subsection (3) of this section may distrain 
John, K.B., (2020)

upon all goods chattels and effects belonging to the debtor wherever the same may be found in Nigeria [72].

viii. Nothing in this section shall be constructed as authorizing the sale of any immovable property without an order of a court of competent jurisdiction [73].

The order obtained under the section is a final and absolute order as it is not granted interim but final determination of the substantive action. In Independent Television/radio $v$ ESBIR [74], the view expressed in favor of the common use of the procedure is that since tax assessment is done every year, saddling the tax authority with the burden of initiating trial for every default in tax payment would result in unending litigation and result in tax defaulters unnecessarily bugging down the tax enforcement authorities.

This assertion is not correct as the litigation for enforcement or recovery of tax due does not end at granting or executing the order of court made ex-patre. It should be pointed out that the goods, proceeds of the execution are kept for 14 days after the distress before they can be sold. This lapse of time will open an opportunity for the tax defaulter to apply to the High Court to seek relief before its expiration. In $I D$ Sam $v$ LIRS [75], the claimant utilized this option.

\section{Matters Arising}

Issues and controversies that trailed the exercise of the power to distrain by the relevant tax authority as an enforcement procedure for the recovery of tax due but unpaid prompts some basic analysis of the imperatives and efficacy of the procedure. Some of the issues include:

\subsection{The provision is self-conflicting}

It will be recalled that the erstwhile section 66 of the Personal Income Tax Act, 2004, which provides for an assessment to be final and conclusive has been repealed. The condition precedent for the invocation of the procedure under section 104 PITA is that the assessment must have been final and conclusive. It is the provision [76] that without prejudice to any other power conferred on the relevant tax authority, the tax authority can invoke the procedure to distrain for the enforcement of payment of tax due from a taxable person who has been properly served with an assessment can only be possible where the assessment has become final and conclusive.

The law itself is self-conflicting; the reason is that the previous sections 61 to 67 of the Principal act relied on by section 104(1) of the Act [77] were deleted by PITA 2011. This brought to an end the "final and conclusive" element of the laws on Personal Income tax. It is, therefore, wrong for the said section 2011 to still be referring to an assessment to being final and conclusive, as it has no basis under the 
John, K.B., (2020)

Tax enforcement procedure under section 104 of personal income tax act: matters arisings

tax law. This was held in Ericsson v BSBIR [78] to be a new dispensation in the Personal Income Tax regime which took effect with the commencement of the Personal Income Tax (Amendment) Act [79]. Owing to the express repeal of the erstwhile applicable section 66 of PITA by section 15 of PITA (Amendment) 2011, it has deleted the principle under the tax jurisprudence. It is therefore an error of law for the makers of the law to have retained the phrase assessment being final and conclusive in section 104 (1) of PITA, 2011.

\subsection{The Provision is Unconstitutional}

Any judicial pronouncement on section 104 of the Personal Income Tax Act without complying with the extant provisions of the constitution [80] is unconstitutional and void. Failure to avail of an aggrieved person or any person to be adversely affected by the decision of a court, body, or tribunal with the opportunity to respond to the case against him constitutes a breach of his right to a fair hearing.

The decisions to be taken under section 104 PITA being too weighty to be taken behind the taxpayer affected, there is a need for the tax payer to be put on notice. The tax authority will be left with unchallenged facts whether they complied with service of notice [81] on the taxpayer or not, where the procedure is conducted exparte. The power vested in the tax authority by the Act [82] to decide whether the taxpayer has been properly served and that the assessment has become "final and conclusive" amounts to over-concentration of power on the tax authority since the proceedings are one-sided.

Note that all the decision taken beginning from the assessment of the taxpayer to the post-assessment is without tax-payers' knowledge. It follows that all the decisions made by the tax authority will be uncontroverted and the court acts merely to rubber-stamp the prior acts of the tax authority. This is a negation of the principles of natural justice. Fair hearing meanings giving equal opportunity to the parties to be heard in the litigation before court [83]. It implies that where parties are given the opportunity to be heard, they cannot complain of a breach of the fair hearing principle. It implies in the procedure followed in the determination of the case, not in the correctness of the decisions [84]. It is important to note that expatre applications are not strictly speaking unconstitutional, but that the orders must be granted in the interim and/or incidental to a substantive action [85].

But the ex-patre order under section 104 is intended to be a final one. It is therefore imperative that the defaulting taxpayer should be given the option of exercising the right of appeal even though the procedure is ex patre [86]. This is the reason for the provision of the Act [87] did not make the judge a robot but vested the judge with the discretion to either take the application made ex patre or order that the other party be put on notice. Ex patre application under the Act is not embedded 
upon any substantive application. It is to be noted that all pre-restraining steps were taken behind the taxpayer, yet the decision of the court is allowed to be taken behind him.

The section under discussion blocks the tax payer's right to access to court completely and makes it possible for the tax authority to determine the rights and obligations in his absence. It is trite that when a statute is revenue-oriented, the provision thereof must be constructed liberally in favor of driving revenue by the government in the interest of the public [88]. When this is the case, courts will be in dilemma between constructing a statutory provision liberally in favor of the revenue than the preservation of fundamental rights entrenched in the constitution. The hand of the court is tied as the court will not have to controvert facts challenging the prior acts of the tax authority to ascertain whether the same comply with the law on its own. The court needs to ascertain and evaluate the standard of reasoning utilized in raising the BOJ assessment, for instance, whether the taxable person was properly served with the assessment and demand notice. This cannot all come from the solitary voice of the tax authority and guess that there would have been a pre-determined answer for it.

\subsection{Distress against Employers and not taxpayers}

The assessment of employees for Personal Income Tax is a matter between the employees and the relevant tax authority. The issue of assessment of Personal Income Tax payable by a taxable person is a matter between the tax authority where the person resides and the taxable person, the taxpayer. It has nothing to do with the employer. The charging or imposition of the tax is governed by statutes that ought to be followed strictly to avoid administering the wrong principles of taxation on taxpayers. In Ericsson v BSBIR [89], a BOJ was raised and the court held amongst other things that by virtue of being an employer, the best of judgment cannot be raised against the Appellant because it is not a taxable person. It is only when the employer fails to remit or deduct the tax and remit to the tax authority that an employer becomes chargeable. Failure to remit the same does not also make him be a taxable person under the Act [90].

In the proceedings, if the taxable person being proceeded against by distress is given an opportunity to be heard, it will be an opportunity to controvert the facts that ordinarily would have been unchallenged in an ex patre application. For instance, the issue concerning standard reasoning, adopted in the BOJ, whether the BOJ complied with the requirements of the law and whether the prior acts of the authority complied with the law. Above all the procedure is detrimental to the taxpayer's right to be informed, assisted, and heard rights of appeal, right to pay not more than the correct amount of tax, right to certainty, and right to confidentiality. 
John, K.B., (2020)

Tax enforcement procedure under section 104 of personal income tax act: matters arisings

It is expected that the judge saddled with the responsibility of adjudicating in an $e x$ patre application should use the blue pencil rule to make the application to be in compliance with the constitution.

\section{Conclusion and Recommendations}

Looking at the procedure for enforcement of tax under section 104 PITA, there is no gain emphasizing the obvious that the special procedure is in conflict with the law. It is an error of law for the section to still contain the phrase final and conclusion which has ceased to be an element in the Personal Income Tax Act or tax jurisprudence. The distraining order provides the tax authority with the judicial plank for enforcement of payment of tax due to the detriment of the taxpayer in all ramifications.

It is unconstitutional for the section to empower the tax authority to take all steps and decisions beginning with an assessment of the taxpayer to service of the notice, the decision on the finality of the assessment and warrant of distress all in the absence of the taxpayer and without his knowledge. As the decisions that followed the use of the ex-patre application is too weighty, the judge should always direct that the taxpayer be put on notice. This is to observe the principles of natural justice, audi alteram partem.

The use of the procedure that is in conflict with the law should not be encouraged. Section 104 should be amended to strike out the offending phrase 'final and conclusive' which is no longer part of the law. Where the element of final and conclusive is deleted, it will place both the tax authority and taxpayer in the same position to choose the procedure to use in the tax enforcement and recovery.

It is also important for the tax authority to determine first, who is the taxable person or taxpayer in relation to section 104 of PITA, 2011. This is so as service of notice of assessment for Personal Income Tax should be served on the individual taxpayer or an employee and not the employer. Procedure to be used against an employer shall take cognizance of the provisions of section 81 (1) (3) and (5) of PITA, 2011. The provisions of sections 81, 82, and 104 of PITA, 2011 must be read together to ascertain which procedure should be used against an employer.

\section{Acknowledgments}

The author thanks the anonymous reviewers and editor for their valuable contribution.

\section{Funding}

This research received no specific grant from any funding agency in the public, commercial, or not-for-profit sectors. 
John, K.B., (2020)

\section{Author Contributions}

The entire article was written by Kachi Bielu John.

\section{Disclosure Statement}

The author has not any competing financial, professional, or personal interests from other parties.

\section{References}

1. Garner, B.A., (ed) (2017). Black's Law Dictionary, 10th ed (USA; Thomson Reuters, St Paul M N, 2014) P.1688.

2. Ayua, I. A., (1966). Nigerian Tax Law (Ibadan: Spectrum's law publishing, 1996) P.9.

3. Constitution of the Federal Republic of Nigeria 1999 (CFRN) as amended, S. 24(F)

4. Umenweke, M. N., Bielu, K.J., (2013). The Best of judgment Assessment by Nigeria Tax Authorities-An Affront to the Rules of Natural Justice? In Multidisciplinary Essays in Honour of BC Egboka; C Arinze-Umobi and F Anyaogu (ed) (Awka: Amaka Dreams Ltd, 2013) pp. 125-145.

\section{Notes}

[1] B.A Garner (ed) Black's Law Dictionary, 10th ed (USA; Thomson Reuters, St Paul M N, 2014) P.1688.

[2] I A Ayua, Nigerian Tax Law (Ibadan: Spectrum's law publishing, 1996) P.9.

[3] (1938) 60 CLR 263 at 276.

[4] Constitution of the Federal Republic of Nigeria 1999 (CFRN) as amended, S. 24(F).

[5] The Holy Bible, Roman Chapter 13 verses 6.

[6] Personal Income Tax Act (PITA) 2011, S.3.

[7] Mathschapi) BV v FBIR (2011) 4TLRN 97, ADDAX v FIRS (2012) 7 TLRN 74, However, compared with the position in Imprest Bakolori v FBIR (2010) 3 TLRN 168 where the tax rate was based on a budget speech.

[8] CFRN, 1999 as amended, S 4(1).

[9] Ibid, S 4(2).

[10] Ibid, S.4(7) (a) \& (b).

[11] Ibid, S.7(5).

[12] Personal Income Tax Act, 2011 (PITA), S.3(1), Companies Income Tax Act, (CITA) 2007, S.9(1), Value Added Tax Act (VAT) 2007, S.2; Stamp Duties Act, Cap S8 LFN 2004, S.3, Capital Gains Tax Act, Cap CI LFN 2004, S.2. it is important to note that the emphasis is on all income, profits or gain.

[13] CGTA, Cap C1 2004, S.26(1), CITA, 2007, S 23(1); PITA, 2011 S.19(10) and Vat, 2007, S.3. 
John, K.B., (2020)

Tax enforcement procedure under section 104 of personal income tax act: matters arisings

[14] PITA, 2011, S.3(1).

[15] Ibid, S.3(1) (a).

[16] Ibid, S.3 (1) (b). This excludes profit of gain from:

a. Medical or dental expenses incurred by the employee.

b. the cost of any passage to or from Nigeria incurred by the employee;

c. any sum paid in respect of the maintenance or education of a child if any provision of this Act provides that any sum received by the employee during a year of assessment shall be deducted from the personal reliefs granted to him for the next following year;

d. So much of any amount of rent the employee is treated as being in receipt equal to the annual amount deemed to be incurred by the employer under section 4 of the Act;

e. So much of any amount of rent the employee is treated as having received under the provisions of section 5 of this Act;

f. So much of the amount of rent subsidy or rent allowance paid is by the employer, to or on account for the employee not exceeding N100,000 per annum;

g. meal subsidy or meal allowance, subject to a maximum of N5,000.00 per annum;

h. Utility allowance of N10,000 per annum;

i. entertainment allowance of N6,000 per annum;

j. Leave grant, subject to a maximum of ten percent of annual basic salary.

[17] Ibid, S.3(1) (c).

[18] Ibid, S.3(1) (d).

[19] Ibid, S.3(1) (e).

[20] Ibid, S.3(1) (f).

[21] Federal Inland Revenue Service is a body established by the Federal Inland Revenue (Establishment) Act (FIRS(E) Act No 13, 2007, S.1.

[22] FIRS (E) Act, 2007, S.2.

[23] Ibid, First Schedule to the Act should be read with such modification to bring them into conformity with the provisions of section 68(2) of FIRS(E) Act.

[24] Ibid, S.8(1).

[25] PITA, 2011, S 87(1).

[26] Ibid, S.88 (1) (a): However, note that section 88(4) provides that functions declared under section 2,6,7,17,46,47,50,53,54,55,57,78,86, 99,102, 103 and 104 must be exercised in the official name of the tax authority simpliciter. See also, Standard Chartered Banks Nigeria Ltd v Kasmal International Services \& 22 ors (unreported decision in appeal No CA/L/437A/2004.

[27] Ibid, S.90(1).

[28] Ibid, S.91(1). It is not clear whether it is the chairman of the Local Government, whom it is to determine the manner in which the committee shall account for the taxes collected or the chairman of the Local Government Revenue Committee created by the Act under s. 91(2).

[29] Ibid, S.2(1) (1). Note section 1A where the state is empowered to collect tax from itinerant workers.

[30] Ibdi, S.2 (1) (b).

[31] Ibid S.108.

[32] Ibid, S.44. 
John, K.B., (2020)

Tax enforcement procedure under section 104 of personal income tax act: matters arisings

[33] Ibid, S.41(1). Note that under the provisions of section 41(10) (b) PITA, a taxable person shall file his returns within 90 days from the commencement of every year of assignment. Again a bonus of $1 \%$ of the tax payable will be granted to a person who files a return under sections 41 and 44 within time.

[34] Ibid, S 41(1) (1).

[35] Ibid, S 41 (1) (b).

[36] Best Children International Schools v FIRS (2019) 4o TLRN 33.

[37] Ibid, S.41(1) (b).

[38] Ibid, S.46 \& 47(1).

[39] Ibid, S 49(1).

[40] But this does not affect any liability otherwise incurred by such person by reason of his failure or neglect to deliver a return.

[41] PITA, 2011, S.54 (2) (a).

[42] Ibid, S 54 (2) (b) and (3).

[43] Ibid, S.47(1) (b) (c) \& 9d). However, for a person engaged in banking shall not be required to disclose any information unless disclosure is required in a letter signed by the chairman of the relevant tax authority.

[44] (2010) 2 TLRN 29.

[45] Ibid, S 53(1).

[46] 7 ALL NTC 427. Note that even if the taxable person has been assessed at a less amount than that which ought to have been charged, the authority may within six years assess the taxable person at such amount or additional amount as ought to have been charged.

[47] (2019) 40 TLRN 53.

[48] PITA, 2011, S.54(1) FBIR v Azigbo Brothers Ltd (2012) 6TLRN 29.

[49] (2011) 4 TLRN 164, Income Tax Commissioner v Badridas Ramarari shop, Akola (1937) LR 64.

[50] 9 All NTC 409.

[51] Supra.

[52] M N Umenweke and KJ Bielu, The Best of judgment Assessment by Nigeria Tax Authorities-An Affront to the Rules of Natural Justice? In Multidisciplinary Essays in Honour of BC Egboka; C Arinze-Umobi and F Anyaogu (ed) (Awka: Amaka Dreams Ltd, 2013) pp. 125-145.

[53] 1-D Sam Ltd v LIRS (2011) 5 TLRN 41, FBIR v Owena motels (2010) 2 TLRN 87.

[54] FBIR v Rezcallah \& sons Ltd, Supra.

[55] PITA, 2011, S.57.

[56] 91999) 11 NWLR (pt. 628) 543 at 555.

[57] Jameldone v FBIR (unreported) Appeal No SC.395/66, 7 Up Bottling Company PIC v LSIRB (2000) (2000) 3 NWLR (pt650) 565.

[58] PITA, 2011, S 58 (1).

[59] (2010) 2 TLRN 86.

[60] 9 ALL NTC 255 at 273.

[61] Order 111 Rules 4 of Tax Appeal Tribunal (Procedure) Rules, 2010. 
Tax enforcement procedure under section 104 of personal income tax act: matters arisings

[62] Ibid, Order Xiv (1).

[63] PITA, 2011. S104 (1) to (8).

[64] PITA, 2011, S 104(1).

[65] Ibid S. 104(1) 9(a).

[66] Ibid S. 104 (1) (b).

[67] Ibid, S. 104 (2).

[68] Ibid, S. 104 (3).

[69] Ibid, S.104 (4).

[70] Ibid S. 104(5).

[71] Ibid S. 104 (6).

[72] Ibid S. 104 (7).

[73] Ibid S. 104 (8).

[74] 9 ALL NTC 421.

[75] Supra, Independent Television /Radio v ESBIR All NTC421, 7UP Bottling Company PLC V Lagos State Inland Revenue Boar 4 ALL NTC 279.

[76] PITA, 2011, S.104 (1).

[77] PITA,2004, SS 66.

[78] Supra.

[79] No 20 of 2011.

[80] Constitution of the Federal Republic of Nigeria, 1999 as amended (CFRN) S. 36(1).

[81] PITA, 2011, S.57.

[82] Ibid, S. 104(1).

[83] Okeke v State (2018) All FWLR (pt.922) 828 at 874.

[84] Akila v Director General, SSS (2014) 2 NWLR (pt. 1392) 443.

[85] Animasham V Bakare (2010) 16 NWLR (pt 1220) 513 at 530.

[86] NS Eng Co. Ltd v OSAM Ltd (2000) 3 NWLR (pt. 649) 403, Guardian Newspaper Ltd v Ag Federation (1995) 5 NWLR (pt.398) 730.

[87] PITA, 2011, S104 (4). It is wrong to state that there is nothing unconstitutional about the ex-patre application, hence, citing the dicta of Uwais JSc (as he then was) in 7UP Bottling Co. Ltd v Abiola \& sons (1995) 2 NWLR (pt.383) 257, that there is no doubt that the right of a fair hearing under the constitution is synonymous with the common law rule of natural justice. However, because of the nature of the certain preliminary steps that have been taken before the commencement of the substantive matter...

[88] Phonics Motors Ltd v NPFMB (1993) NWLR (pt. 272) 718.

[89] Supra.

[90] PITA 2011, S.54 (3) \& (4). 